\title{
Environmental inventory modelling of the use of compost and peat in growth media preparation
}

Boldrin, Alessio; Hartling, Karin R.; Laugen, Maria; Christensen, Thomas Højlund

Published in:

Resources, Conservation and Recycling

Link to article, DOI:

10.1016/j.resconrec.2010.04.003

Publication date:

2010

Document Version

Peer reviewed version

Link back to DTU Orbit

Citation (APA):

Boldrin, A., Hartling, K. R., Laugen, M., \& Christensen, T. H. (2010). Environmental inventory modelling of the use of compost and peat in growth media preparation. Resources, Conservation and Recycling, 54(12), 12501260. https://doi.org/10.1016/j.resconrec.2010.04.003

\section{General rights}

Copyright and moral rights for the publications made accessible in the public portal are retained by the authors and/or other copyright owners and it is a condition of accessing publications that users recognise and abide by the legal requirements associated with these rights.

- Users may download and print one copy of any publication from the public portal for the purpose of private study or research.

- You may not further distribute the material or use it for any profit-making activity or commercial gain

- You may freely distribute the URL identifying the publication in the public portal 


\title{
Environmental inventory modelling of the use of compost and peat in growth media preparation
}

Alessio Boldrin, Karin R. Hartling, Maria Laugen, \& Thomas H. Christensen

\author{
Department of Environmental Engineering \\ Technical University of Denmark \\ Kongens Lyngby, Denmark
}

\begin{abstract}
"NOTE: this is the author's version of a work that was accepted for publication in Resource, Conservation and Recycling journal. Changes resulting from the publishing process, such as peer review, editing, corrections, structural formatting, and other quality control mechanisms may not be reflected in this document. Minor changes may have been made to this manuscript since it was accepted for publication.

A definitive version is published in Resource, Conservation and Recycling, vol 54, pp 1250-1260, doi:10.1016/j.resconrec.2010.04.003"
\end{abstract}




\begin{abstract}
Compost produced from biological treatment of organic waste has a potential for substituting peat in growth media preparation. The Life Cycle Inventories (LCls) of the two alternatives were compared using LCA-modelling (EASEWASTE) considering a 100 year period and a volumetric substitution ratio of 1:1. For the compost alternative, the composting process, growth media use, and offsetting of mineral fertilizers were considered. For the peat alternative, peat-land preparation, excavation, transportation, and growth media use were considered. It was assumed that for compost $14 \%$ of the initial carbon was left in the soil after 100 years, while all carbon in peat was mineralized. With respect to greenhouse gas emissions, the former is considered a saving, while the later is considered an emission, because peat in a peatland is considered stored biogenic carbon. The leaching during the growth media use was assessed by means of batch leaching tests involving 4 compost samples and 7 peat samples. The compost leached 3-20 times more heavy metals and other compounds than the peat. The life-cycle-assessment showed that compost performs better regarding global warming (savings in the range of 70-150 $\mathrm{kg} \mathrm{CO}_{2}$-eq. $\mathrm{Mg}^{-1}$ ) and nutrient enrichment (savings in the range of 1.7-6.8 $\mathrm{kg} \mathrm{NO}_{3} \mathrm{Mg}^{-1}$ compost), while peat performs better in some toxic categories, because of the lower content of heavy metals.
\end{abstract}

Keywords: peat, compost, organic waste, LCl, leachate, EASEWASTE

List of abbreviations:

EU: European Union

GHG: Greenhouse gases

GWC: Garden Waste Compost

GWP: Global Warming Potential

KWC: Kitchen Waste Compost

LCA: Life Cycle Assessment

LCl: Life Cycle Inventory

PE: Polyethylene 


\section{Introduction}

Growth media is used in horticulture, in professional gardening and landscaping, and in private gardens for lawns, pots and plant beds. Growth media typically consists of an organic component, fertilizer, and sand or sandy soil. The organic component is often peat excavated from natural bogs or fens. Peat is plant debris that in its natural setting is degrading very slowly and thus peat can be considered bound biogenic carbon. However, excavated peat used in a growth media will degrade over a few decades and emit the bound carbon as $\mathrm{CO}_{2}$. Thus $\mathrm{CO}_{2}$ released by degradation of peat should be counted as a greenhouse gas (GHG). This is an issue that must be addressed since almost $80 \%$ of growth media used in Europe is constituted of peat materials (IPS, 2007).

Compost produced from organic waste from residential areas could be an alternative to the use of peat in growth media. The organic residential waste, in terms of kitchen organics and garden waste, originates from relative short-term crops and vegetation and thus $\mathrm{CO}_{2}$ released from its degradation can be considered neutral with respect to GHG (Christensen et al., 2009).

However, comparison of the use of compost and peat in growth media production should also pay attention - in addition to differences in carbon releases - to differences in the need of transport, the fertilizer content, the content of contaminants, and the leaching of nutrients and contaminants into the subsoil. To our knowledge no comprehensive data-set exists to support such a comparison.

This study presents life cycle inventories for compost and peat used in growth media. The inventories include exchanges with the environment from the production, transportation and utilization for a total period of 100 years. Leaching of substances to groundwater was assessed by means of batch leaching tests. The provided inventories can be used in comparison of alternative management scenarios for residential organic waste involving composting and substitution of peat in growth media preparation. As an illustrative example, the life-cycle-inventories (LCI) provided were used in a lifecycle-assessment (LCA) of alternative management of residential organic waste in order to illustrate the importance of detailed LCls for compost and peat use in growth media production.

\subsection{Peat}

Peat is an accumulation of organic detritus that forms in anoxic, waterlogged and acidic conditions of bogs and fens. Peat can be excavated and used either as a fuel or as a soil amendment in the plant production industry. In 1999, about 100 million cubic metres of peat were produced worldwide (Joosten \& Clarke, 2002), of which 65\% was used for energy purposes and $35 \%$ in the horticultural sector. The majority of peat is produced in temperate northern countries i.e. the countries of the former USSR, Canada, USA, Scandinavia and Finland. In 2000, Canada produced around $1.3^{*} 10^{6} \mathrm{Mg}$ of peat, being the largest producer of peat for horticultural purposes in the world (Cleary et al., 2005).

Peatlands are significant reservoirs of carbon. Carbon in peat in boreal and temperate regions is estimated to be around one third of the carbon stored in the world's soils (Gorham, 1991) or 500 Pg (IPCC, 2003). Carbon accumulation in the form of peat occurs over a long period of time as a result of degradation of plant material under anaerobic conditions and could play a major role in the global carbon cycle. 
According to Joosten \& Clarke (2002), about 5-10\% of the biomass (and thus carbon) produced annually in the peatland area ends up in the peat stock.

The impact of peatlands on climate change is determined by the net emissions of $\mathrm{CO}_{2}, \mathrm{CH}_{4}$ and $\mathrm{N}_{2} \mathrm{O}$, depending on the environmental (e.g. deepness of the bog) and geographic conditions, type and age of the peatland and land-use (Lappalainen, 1996). For example, fens (a type of wetland), which receive groundwater and are dominated by vascular plant vegetation, emit more $\mathrm{CH}_{4}$ than bogs dominated by Sphagnum moss (Lappalainen, 1996).

Extraction of peat disturbs the natural cycle of carbon in peatlands. Lowering of the water table due to drainage increases the depth of the aerobic layer and therefore $\mathrm{CO}_{2}$ emissions are increased. $\mathrm{CH}_{4}$ emissions generally cease following drainage. The removal of plant cover in areas converted to peat production also terminates the accumulation of plant debris and thence the $\mathrm{CO}_{2}$ sequestration (Lappi \& Byrne, 2004). Degradation of dewatered peat (into carbon containing gases including $\mathrm{CO}_{2}$ ) could result in emissions in the order of at least 7.4 $\mathrm{Mg} \mathrm{CO}_{2}$-eq. hectare $^{-1}$ year $^{-1}$ (Reijnders \& Huijbregts, 2003).

Transportation and biological decomposition of excavated peat are also contributing to greenhouse gas (GHGs) emissions during the peat life cycle. Being mainly produced in northern areas of the world, peat is often transported very far by different means of transportation. Regarding decomposition, both Smith et al. (2001) and Cleary et al. (2005) report that within 100 years all peat used outdoor is completely degraded and all carbon contained is consequently released to the atmosphere, primarily as $\mathrm{CO}_{2}$. Release of this $\mathrm{CO}_{2}$ is accounted as a GHG in this study, because of the long natural cycle (i.e. centuries to millennia) of carbon in peatlands.

\subsection{Compost}

Various technologies exist to produce compost from residential biowaste such as kitchen organics and garden waste. Composts and compost-containing products are already widely used in different areas, e.g. for agricultural purposes, landscaping, soil reclamation, organic farming, private gardening, erosion control, roadside projects and nurseries. In the European Union (EU) $70-80 \%$ of compost is used for agriculture, landscaping, nurseries etc. while the remaining 20-30\% is used by residential garden owners. Compost is locally produced and thus transportation of the compost is short before use. Beside organic matter, compost also contains nutrients and, depending on its origin, a certain content of contaminants, in particular heavy metals. Nutrients as well as metals may leach into the subsoil when compost is used on land.

\section{Materials and methods}

For the development of the life-cycle-inventories, data were collected from the literature and supplemented with experimental data regarding the composition of peat and the potential leaching from peat as well as from compost.

\subsection{Samples}

Four samples of compost were collected at composting facilities in Denmark, and seven samples of peat were collected either at production sites or at commercial sites where peat materials were sold as growth media. Details are presented in Table 1. Both peat and compost were stored shortly in tight plastic barrels before being tested. 
Dry matter content of all samples was measured by heating 80-200 g of sample at $55{ }^{\circ} \mathrm{C}$ until water evaporation was completed (at least 24 hours). Afterwards, samples were sent to a certified external lab (former Analytica $A B$, now ALS Scandinavia $A B$, Luleå, Sweden) for chemical and physical characterization (Table 2).

Table 1 - Compost and peat samples

\begin{tabular}{lllcc}
\hline Material & & Producer & Country & Collection \\
\hline Compost & Kitchen waste (KWC) & Solum A/S & DK & Composting plant \\
& Garden waste (GWC) & Solum A/S & DK & Composting plant \\
& & Århus Affaldscenter & DK & Composting plant \\
& & RGS90 & DK & Composting plant \\
\hline Peat & Sphagnum & Unimuld & DK & Commercial \\
& Sphagnum & Sphagnum BG & SE & Commercial \\
& Peat & Scan Muld & SE & Commercial \\
& Sphagnum & Moss Peat & LT & Commercial \\
& Peat & Bord Na Mona & IE & Production site \\
& White Peat & Vapo & FI & Production site \\
& Brown Peat & Vapo & FI & Production site \\
\hline
\end{tabular}

DK: Denmark, SE: Sweden, LT: Lithuania, IE: Ireland, FI: Finland

\subsection{Leaching tests}

Leaching tests (on wet material) were performed in 2 litres Polyethylene (PE) bottles, where 200-300 g of test material and water were mixed at a liquid-to-solid ratio (L/S) of $10 \mathrm{l} / \mathrm{kg}$ dry material. The bottles were rotated for approximately 24 hours. Liquid and solids were separated through several steps. A first coarse filtration was done with a nylon filter, followed by centrifugation for 8 minutes at 2500 rpm. Finally, filtrations with a GF/C filter and a $0.45 \mu \mathrm{m}$ filter were performed. Filtrations through the nylon and GF/C filters were enhanced by suction with a vacuum pump. Three samples were taken from the remaining liquid: one $40 \mathrm{ml}$ sample for heavy metals analysis (conserved as $2 \%$ nitric acid) and two $50 \mathrm{ml}$ samples for organic carbon and anion analysis (conserved in freezer to stop any biological activity). To avoid heavy metals contamination, all equipment used was initially acid washed in a $3 \mathrm{M}$ nitric acid solution and washed again with $1 \mathrm{ml}-\mathrm{HNO}_{3} / 500 \mathrm{ml}$ water between one sample and the next.

The organic carbon in the leachate was measured as Non-Purgeable Organic Carbon (NPOC). The analysis was performed on a Shimadzu TOC 5000A with auto sampler ASI5000. Dilution was necessary to measure concentrations within the detection range. Anions measured in the samples comprised chloride, bromide, nitrate and sulphate. The analysis was performed on a Dionex DX-120 Ion Chromatograph. Heavy metal content, both in solids and leachate, was analysed by a certified external lab (ALS Scandinavia $A B$, Luleå, Sweden).

Reliability of the analysis was assessed. For each of the described methods, two replicates of randomly selected samples were analysed. No significant differences were found. 
Table 2 - Chemical composition of peat and compost (kitchen waste compost, KWC, and garden waste compost, GWC).

\begin{tabular}{|c|c|c|c|c|}
\hline \multirow[b]{2}{*}{ Parameter } & \multirow[b]{2}{*}{ Unit } & \multicolumn{3}{|c|}{ Material } \\
\hline & & Peat* & KWC** & GWC*** \\
\hline TS & $\% w w$ & $43.6 \pm 4.7$ & 50.4 & $64.4 \pm 7.4$ \\
\hline VS & $\%$ TS & $96.9 \pm 1.7$ & 30.9 & $24.9 \pm 2.5$ \\
\hline Ash & $\%$ TS & $3.1 \pm 1.7$ & 69.1 & $75.1 \pm 2.5$ \\
\hline $\mathbf{S}$ & $\%$ TS & $0.17 \pm 0.11$ & 0.45 & $0.12 \pm 0.02$ \\
\hline Tot-Cl & $\%$ TS & $0.06 \pm 0.02$ & 0.08 & $0.05 \pm 0.04$ \\
\hline $\mathbf{F}$ & $\%$ TS & $<0.01$ & $<0.01$ & $<0.04$ \\
\hline Tot-C & $\%$ TS & $50.4 \pm 1.5$ & 19.1 & $14.3 \pm 2.3$ \\
\hline H & $\%$ TS & $5.5 \pm 0.1$ & 2.1 & $1.5 \pm 0.26$ \\
\hline Tot-N & $\%$ TS & $1.0 \pm 0.3$ & 1.2 & $0.86 \pm 0.07$ \\
\hline 0 & $\%$ TS & $39.6 \pm 2.0$ & 7.2 & $7.5 \pm 1.3$ \\
\hline C:N & & $48 \pm 10$ & 15.9 & $16.6 \pm 1.8$ \\
\hline Cal. value & $\mathrm{MJ} / \mathrm{kg} \mathrm{TS}$ & $19.4 \pm 0.9$ & 6.6 & $4.7 \pm 0.39$ \\
\hline Cal. value & $\mathrm{MJ} / \mathrm{kg}$ ww & $8.4 \pm 0.9$ & 2.8 & $3.2 \pm 0.52$ \\
\hline Density & $\mathrm{kg} / \mathrm{m}^{3}$ & $200 \pm 57$ & 726 & $684 \pm 114$ \\
\hline As & $\mathrm{mg} / \mathrm{kg} \mathrm{TS}$ & $0.9 \pm 0.5$ & 6.5 & $3.7 \pm 0.28$ \\
\hline $\mathrm{Ba}$ & $\mathrm{mg} / \mathrm{kg} \mathrm{TS}$ & $18 \pm 10$ & 320 & $343 \pm 51$ \\
\hline $\mathrm{Be}$ & $\mathrm{mg} / \mathrm{kg} \mathrm{TS}$ & $0.06 \pm 0.06$ & 0.73 & $0.82 \pm 0.1$ \\
\hline Cd & $\mathrm{mg} / \mathrm{kg} \mathrm{TS}$ & $0.12 \pm 0.09$ & 0.62 & $0.37 \pm 0.14$ \\
\hline Co & $\mathrm{mg} / \mathrm{kg} \mathrm{TS}$ & $0.27 \pm 0.09$ & 3.6 & $3.1 \pm 0.32$ \\
\hline $\mathrm{Cr}$ & $\mathrm{mg} / \mathrm{kg} \mathrm{TS}$ & $1.8 \pm 1.0$ & 18 & $29 \pm 4.9$ \\
\hline $\mathrm{Cu}$ & $\mathrm{mg} / \mathrm{kg} \mathrm{TS}$ & $1.7 \pm 0.8$ & 135 & $36 \pm 12$ \\
\hline $\mathrm{Hg}$ & $\mathrm{mg} / \mathrm{kg} \mathrm{TS}$ & $0.06 \pm 0.04$ & 0.53 & $0.14 \pm 0.12$ \\
\hline Mo & $\mathrm{mg} / \mathrm{kg} \mathrm{TS}$ & $<0.28$ & $<4.0$ & $<4.2$ \\
\hline $\mathrm{Nb}$ & $\mathrm{mg} / \mathrm{kg} \mathrm{TS}$ & $<0.30$ & $<4.0$ & $<5.2$ \\
\hline $\mathbf{N i}$ & $\mathrm{mg} / \mathrm{kg} \mathrm{TS}$ & $0.8 \pm 0.35$ & 13.5 & $7.2 \pm 1.0$ \\
\hline $\mathrm{Pb}$ & $\mathrm{mg} / \mathrm{kg} \mathrm{TS}$ & $10 \pm 10$ & 28 & $34 \pm 18$ \\
\hline Sb & $\mathrm{mg} / \mathrm{kg} \mathrm{TS}$ & $0.13 \pm 0.13$ & 0.23 & $0.08 \pm 0.02$ \\
\hline Sc & $\mathrm{mg} / \mathrm{kg} \mathrm{TS}$ & $0.25 \pm 0.22$ & 1.8 & $2.8 \pm 0.77$ \\
\hline Sn & $\mathrm{mg} / \mathrm{kg} \mathrm{TS}$ & $<0.85$ & $<20$ & $<20$ \\
\hline Sr & $\mathrm{mg} / \mathrm{kg} \mathrm{TS}$ & $16 \pm 7.6$ & 279 & $140 \pm 4.2$ \\
\hline $\mathbf{V}$ & $\mathrm{mg} / \mathrm{kg} \mathrm{TS}$ & $2.2 \pm 1.3$ & 24 & $26 \pm 4.5$ \\
\hline $\mathbf{W}$ & $\mathrm{mg} / \mathrm{kg} \mathrm{TS}$ & $<2.2$ & $<40$ & $<42$ \\
\hline $\mathbf{Y}$ & $\mathrm{mg} / \mathrm{kg} \mathrm{TS}$ & $0.90 \pm 1.0$ & 8.0 & $11 \pm 1.4$ \\
\hline $\mathrm{Zn}$ & $\mathrm{mg} / \mathrm{kg} \mathrm{TS}$ & $11 \pm 6.0$ & 395 & $154 \pm 45$ \\
\hline $\mathrm{Zr}$ & $\mathrm{mg} / \mathrm{kg} \mathrm{TS}$ & $5.5 \pm 4.2$ & 124 & $131 \pm 16$ \\
\hline Si & $\mathrm{g} / \mathrm{kg} \mathrm{TS}$ & $7.8 \pm 5.5$ & 187 & $241 \pm 9.2$ \\
\hline Al & $\mathrm{g} / \mathrm{kg} \mathrm{TS}$ & $1.4 \pm 1.2$ & 22 & $25 \pm 3.0$ \\
\hline $\mathrm{Ca}$ & $\mathrm{g} / \mathrm{kg} \mathrm{TS}$ & $2.6 \pm 1.4$ & 81 & $26 \pm 2.6$ \\
\hline $\mathrm{Fe}$ & $\mathrm{g} / \mathrm{kg} \mathrm{TS}$ & $1.0 \pm 0.56$ & 18 & $13 \pm 3.0$ \\
\hline K & $\mathrm{g} / \mathrm{kg} \mathrm{TS}$ & $0.57 \pm 0.42$ & 11 & $17 \pm 1.4$ \\
\hline Mg & $\mathrm{g} / \mathrm{kg} \mathrm{TS}$ & $1.1 \pm 0.34$ & 3.7 & $3.1 \pm 0.20$ \\
\hline Mn & $\mathrm{g} / \mathrm{kg}$ TS & $0.002 \pm 0.01$ & 0.50 & $0.33 \pm 0.12$ \\
\hline $\mathrm{Na}$ & $\mathrm{g} / \mathrm{kg} \mathrm{TS}$ & $0.38 \pm 0.27$ & 4.2 & $6.5 \pm 0.83$ \\
\hline $\mathbf{P}$ & $\mathrm{g} / \mathrm{kg} \mathrm{TS}$ & $0.21 \pm 0.05$ & 9.3 & $1.7 \pm 0.24$ \\
\hline Ti & $\mathrm{g} / \mathrm{kg} \mathrm{TS}$ & $0.01 \pm 0.06$ & 1.4 & $1.4 \pm 0.22$ \\
\hline
\end{tabular}




\subsection{LCI/ LCA-modelling}

The life-cycle-inventory modelling was done by means of the EASEWASTE model developed at the Technical University of Denmark for environmental assessment of integrated solid waste management (Kirkeby et al., 2006). The model contains submodels for transport, composting, and use of compost in agriculture as well as other waste management technologies. The LCls of compost and peat were compared by the impact assessment available in EASEWASTE, including the EDIP method (Wenzel et al., 1997) and further up-dates (Stranddorf et al., 2005). The impact potentials were normalized by one person-equivalent, which is the annual load from one person from all activities (housing, food, transportation etc.) according to Stranddorf et al. (2005); see Table 3. The developed inventories can be useful in quantitative comparison with a range of other alternatives for organic waste management, for example incineration, composting for use in agriculture, anaerobic digestion and landfilling.

As an illustration two scenarios for organic kitchen waste were compared by means of LCA: (baseline scenarios) landfilling of kitchen organics together with other municipal waste in a landfill with gas recovery and production of electricity substituting for electricity produced from coal burning, and (recycling scenario) source separation and composting of kitchen organics and use of the compost in growth media production as a substitution for peat. The baseline scenario was modelled in EASEWASTE by means of existing default databases, while the recycling scenario was obtained directly from the developed LCls by considering that $1 \mathrm{Mg}$ of organic kitchen waste results in $430 \mathrm{~kg}$ of compost.

Table 3 - Normalisation references for environmental impact categories in EDIP1997 (Stranddorf et al., 2005)

\begin{tabular}{|c|c|c|c|}
\hline Impact category & $\begin{array}{l}\text { Geographical } \\
\text { scale }\end{array}$ & $\begin{array}{c}\text { Characterisation } \\
\text { unit }\end{array}$ & $\begin{array}{c}\text { Normalization } \\
\text { reference } \\
\text { [Characterisation } \\
\text { unit/person/year] }\end{array}$ \\
\hline \multicolumn{4}{|l|}{ Non-toxic impacts } \\
\hline Global warming (GW) & Global & $\mathrm{kg} \mathrm{CO}$-equivalents & $8.7 \cdot 10^{3}$ \\
\hline Acidification (AC) & Regional & $\mathrm{kg} \mathrm{SO}_{2}$-equivalents & $7.4 \cdot 10^{1}$ \\
\hline Nutrient enrichment (NE) & Regional & kg NO${ }_{3}$-equivalents & $1.19 \cdot 10^{2}$ \\
\hline Photochemical ozone formation (POF) & Regional & $\mathrm{kg} \mathrm{C}_{2} \mathrm{H}_{4}$-equivalents & $2.5 \cdot 10^{1}$ \\
\hline \multicolumn{4}{|l|}{ Toxic impacts } \\
\hline \multicolumn{4}{|l|}{ Human toxicity (HT) } \\
\hline - via air & Local & $\mathrm{m}^{3}$ air & $6.09 \cdot 10^{10}$ \\
\hline Persistent toxicity (PT), average of: & Regional & & \\
\hline - Human toxicity via water & & $\mathrm{m}^{3}$ water & $5.22 \cdot 10^{4}$ \\
\hline - Human toxicity via soil & & $\mathrm{m}^{3}$ soil & $1.27 \cdot 10^{2}$ \\
\hline - Ecotoxicity via water & & $\mathrm{m}^{3}$ water & $3.52 \cdot 10^{5}$ \\
\hline - Ecotoxicity via soil & & $\mathrm{m}^{3}$ soil & $9.64 \cdot 10^{5}$ \\
\hline - Spoiled groundwater resources & Local & $\mathrm{m}^{3}$ groundwater & 140 \\
\hline
\end{tabular}

\section{Results}

The results of the study are presented in terms of the leaching test data, the $\mathrm{LCl}$ tables of three growth media (compost from kitchen organics, compost from garden waste, peat), a comparison of the life-cycle impacts associated with the $\mathrm{LCl}$ tables, and finally the results of the illustrative example. 


\subsection{Results of the leaching tests}

Table 4 reports average chemical compositions of leachate from peat and compost. The average was calculated aggregating results for samples presented in Table 1 . This was done because leachates from different compost samples had similar chemical profiles, indicating that the compost products were more or less similar with respect to leaching, regardless of their origin. The same applied for the peat leachates. Peat leachate had a load of pollutants 3-20 times lower than leachate from compost. In some cases, drinking water limits were exceeded for some compounds.

The conductivity measured in the leachate was approximately 10 times higher in the compost leachate than in the peat leachate. The high salinity of the compost leachate can cause "burning" of the plant roots when compost is used in growth media if not sufficiently diluted by soil and sand.

Table 4 - Chemical composition of peat and compost leachate (L/S 10). (kitchen waste compost, KWC, and garden waste compost, GWC).

\begin{tabular}{|c|c|c|c|c|}
\hline Element & Unit & Peat* & KWC** & GWC*** \\
\hline $\mathrm{Ca}$ & $\mathrm{mg} / \mathrm{l}$ & $2.2 \pm 1.4$ & 132 & $38 \pm 16$ \\
\hline $\mathrm{Fe}$ & $\mathrm{mg} / \mathrm{l}$ & $0.24^{\dagger} \pm 0.25$ & $5.1^{\dagger}$ & $1.8^{\dagger} \pm 0.55$ \\
\hline K & $\mathrm{mg} / \mathrm{l}$ & $2.4 \pm 0.86$ & $212^{+}$ & $278^{\dagger} \pm 19$ \\
\hline Mg & $\mathrm{mg} / \mathrm{l}$ & $1.8 \pm 1.25$ & 20 & $8.5 \pm 4.6$ \\
\hline $\mathrm{Na}$ & $\mathrm{mg} / \mathrm{l}$ & $8.7 \pm 3.4$ & 42 & $28 \pm 8.6$ \\
\hline $\mathbf{S}$ & $\mathrm{mg} / \mathrm{l}$ & $3.1 \pm 2.7$ & 118 & $10 \pm 8.4$ \\
\hline Al & $\mu \mathrm{g} / \mathrm{l}$ & $224^{\ddagger} \pm 297$ & $3290^{\ddagger}$ & $1897^{\ddagger} \pm 564$ \\
\hline As & $\mu \mathrm{g} / \mathrm{l}$ & $<2.3$ & $43^{\ddagger}$ & $41^{\ddagger} \pm 3.8$ \\
\hline $\mathrm{Ba}$ & $\mu \mathrm{g} / \mathrm{l}$ & $373 \pm 254$ & 380 & $288 \pm 151$ \\
\hline Cd & $\mu \mathrm{g} / \mathrm{l}$ & $<0.14$ & 0.18 & $0.44 \pm 0.08$ \\
\hline Co & $\mu \mathrm{g} / \mathrm{l}$ & $0.28 \pm 0.17$ & 2.2 & $3.6 \pm 1.4$ \\
\hline $\mathrm{Cr}$ & $\mu \mathrm{g} / \mathrm{l}$ & $<0.71$ & 4.1 & $2.2 \pm 0.68$ \\
\hline $\mathrm{Cu}$ & $\mu \mathrm{g} / \mathrm{l}$ & $<1.4$ & 47 & $40 \pm 16$ \\
\hline $\mathrm{Hg}$ & $\mu \mathrm{g} / \mathrm{l}$ & $<0.20$ & $<0.20$ & $<0.24$ \\
\hline$M n$ & $\mu \mathrm{g} / \mathrm{l}$ & $20 \pm 22$ & $261^{\dagger}$ & $280^{\dagger} \pm 138$ \\
\hline $\mathrm{Ni}$ & $\mu \mathrm{g} / \mathrm{l}$ & $2.8 \pm 1.0$ & 24 & $11 \pm 1.3$ \\
\hline $\mathrm{Pb}$ & $\mu \mathrm{g} / \mathrm{l}$ & $2.4 \pm 1.6$ & 16 & $19 \pm 9.8$ \\
\hline $\mathrm{Zn}$ & $\mu \mathrm{g} / \mathrm{l}$ & $486^{\dagger} \pm 293$ & $450^{\dagger}$ & $314^{\dagger} \pm 51$ \\
\hline Mo & $\mu \mathrm{g} / \mathrm{l}$ & $<0.50$ & 52 & $10 \pm 2.2$ \\
\hline $\mathrm{Sb}$ & $\mu \mathrm{g} / \mathrm{l}$ & $<0.11$ & $8.3^{+}$ & $1.9^{\dagger} \pm 0.84$ \\
\hline NPOC & $\mu \mathrm{g} / \mathrm{l}$ & $153 \pm 73$ & 200 & $147 \pm 47$ \\
\hline Chloride & $\mathrm{mg} / \mathrm{l}$ & $8.2 \pm 3.5$ & 99 & $108 \pm 17$ \\
\hline Bromide & $\mathrm{mg} / \mathrm{l}$ & 0 & 0 & $3.7 \pm 6.1$ \\
\hline Nitrate & $\mathrm{mg} / \mathrm{l}$ & $2.0 \pm 1.5$ & 19 & $12 \pm 13$ \\
\hline Sulphate & $\mathrm{mg} / \mathrm{l}$ & $2.1 \pm 2.3$ & 99 & $7.4 \pm 7.0$ \\
\hline \multicolumn{5}{|c|}{$\begin{array}{l}\text { * standard deviation calculated on } 7 \text { samples of peat } \\
\text { *** standard deviation not calculated, because results regard a single sample } \\
\text { *** standard deviation calculated on } 3 \text { samples of GWC } \\
\text { Exceeding Danish drinking water limits } \\
\text { Exceeding WHO drinking water guidelines }\end{array}$} \\
\hline
\end{tabular}

\subsection{Life cycle inventory ( $L C I)$ for compost}

The inventory is built based on the EASEWASTE module for biotechnologies (Kirkeby et al., 2006). Collection and transportation of waste were not included since they could be very variable and the waste should in any case always be collected for treatment. 
Figure 1 presents the life cycle inventory boundaries of compost considered. Specific data for the composting process and the use on land were taken from the EASEWASTE database (2008). Relevant parameters are reported in Table 5.

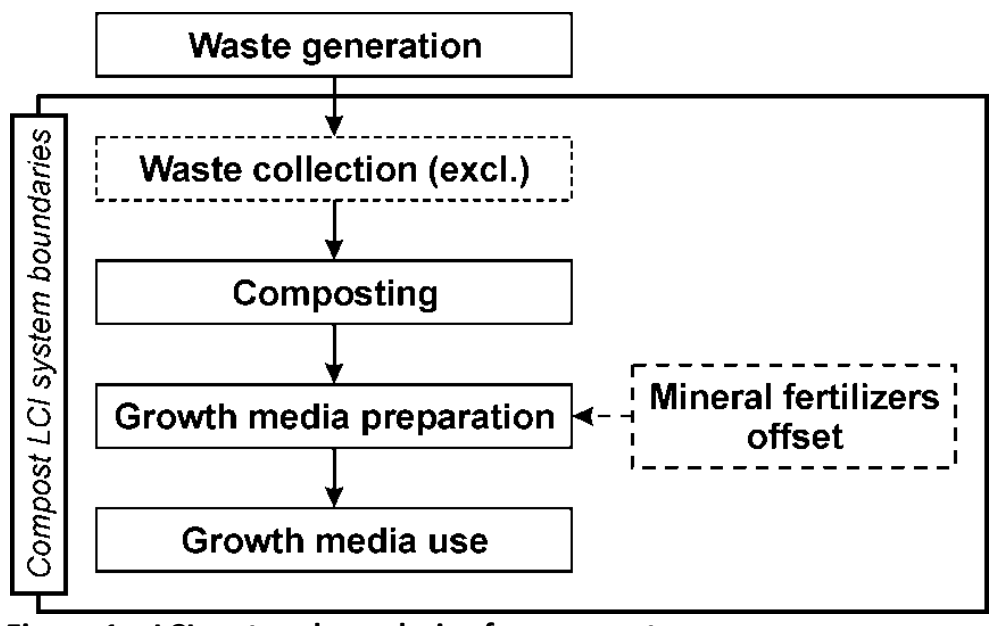

Figure 1 - LCl system boundaries for compost.

Table 5 - EASEWASTE modelling of the composting process and use on land. Data in brackets represent ranges of values found in literature.

\begin{tabular}{|c|c|c|c|c|}
\hline Life cycle stage & Parameter & Unit & KWC & GWC \\
\hline \multirow[t]{4}{*}{ Composting } & $\mathrm{N}-\mathrm{NH}_{3}$ & $\%$ of $\mathrm{N}$-loss & 0.1 & 2.4 \\
\hline & $\mathrm{N}-\mathrm{N}_{2} \mathrm{O}$ & $\%$ of $\mathrm{N}$-loss & 1.8 & $1.4(0.5-1.8)^{*}$ \\
\hline & $\mathrm{CH}_{4}$ & $\%$ of degraded C & $0(0-3)^{*}$ & $2.1(2.1-2.7)^{*}$ \\
\hline & $\mathrm{CO}$ & $\mathrm{kg} / \mathrm{Mg}_{\text {waste }}$ & - & 0.05 \\
\hline \multirow[t]{5}{*}{ Use on land } & $\mathbf{N H}_{3}$ evaporation & $\%$ of $\mathrm{NH}_{3}$ & 1.6 & $(1.6-4.5)^{* *}$ \\
\hline & $\mathrm{N}-\mathrm{N}_{2} \mathrm{O}$ formation & $\%$ total N & 1.5 & $(1.3-2.2)^{* *}$ \\
\hline & $\mathrm{NO}_{3}^{-}$leaching & $\%$ of $\mathrm{NO}_{3}^{-}$ & 20 & $(3-22)^{* *}$ \\
\hline & $\mathrm{NO}_{3}^{-}$runoff & $\%$ of $\mathrm{NO}_{3}^{-}$ & 20 & $(4-30)^{* *}$ \\
\hline & Carbon binding 100 -year & $\%$ of C & 14 & $(9-14)^{* *}$ \\
\hline
\end{tabular}

* From Boldrin et al. (2009)

* From Bruun et al. (2006)

Two types of compost were considered: kitchen waste compost (KWC) and garden waste compost (GWC).

Kitchen waste compost (KWC) is assumed to be produced in a closed-building tunnel composting plant, where $1 \mathrm{Mg}$ of compost is produced from an input of 2.33 $\mathrm{Mg}$ of green waste. Feedstock to the process is: $50 \%$ organic kitchen waste, $30 \%$ garden waste, $20 \%$ material recirculated from screening. $49 \%$ of the $\mathrm{N}$ input is lost during the process. Specific air emissions are reported in Table 5. These represent emissions after the biofilter ( $95 \%$ removal of $\mathrm{NH}_{3}$ and $\mathrm{CH}_{4}$, no removal of $\mathrm{N}_{2} \mathrm{O}$ ). The facility consumes $51 \mathrm{KWh}$ of electricity per $\mathrm{Mg}$ of waste treated. Both the energy consumption and the emissions are in the mid-upper end of data reported in literature for enclosed composting facilities shown in Boldrin et al. (2009).

Garden waste compost (GWC) is assumed to be produced in an outdoor windrow composting plant, which is the most common treatment for garden waste in many European countries (Andersen et al., 2009). In this facility, $1 \mathrm{Mg}$ of compost is produced from an input of $1.48 \mathrm{Mg}$ of garden waste. Feedstock to the process is: $100 \%$ garden waste (although a certain percentage could be recirculated from screening). $3 \%$ of the $\mathrm{N}$ input is lost during the process. Specific air emissions are reported in Table 5. 
No biofilter is installed for treatment of off-gasses. The facility consumes 4.1 litres of diesel per Mg of waste treated. The used dataset - energy consumption and process emissions - is quite typical for open-windrow composting facilities, as shown in Boldrin et al. (2009).

Compost is used in preparation of enriched growth media. The N, P, K content of the compost is assumed to replace mineral fertilizers (see Table 2) considering the following substitution coefficient: $20 \%$ for $\mathrm{N}, 100 \%$ for $\mathrm{P}$, and $100 \%$ for $\mathrm{K}$. LCls for mineral fertilizers production were defined according to Hansen et al. (2006). Other emissions during 100 years after application to land of the enriched media were calculated according to the coefficients reported in Table 5 (taken from Bruun et al., 2006).

In the assessment, it is considered that $14 \%$ of carbon contained in compost is still bound to soil after 100 years (time horizon of the assessment) and can be considered an avoided emission of biogenic $\mathrm{CO}_{2}$ (Christensen et al., 2009). The potential for carbon binding in soils by compost amendment is acknowledged in several studies (e.g. Marmo, 2008); the actual value of $14 \%$ of $C$ being sequestered is identical to the binding estimated by agro-ecological modelling of compost use on farm land with a typical Danish crop rotation scheme (see Bruun et al., 2006).

The compost $\mathrm{LCl}$ is given in Table 6. Please note that - due to lack of space some of the resources are not terminated, meaning that the $\mathrm{LCl}$ datasets for the production or the use of such resources are not calculated and incorporated in the presented inventory. The leaching of substance to groundwater is calculated according to the leachate composition presented in table 4. Emissions to soil are calculated as difference between the input of substance (Table 2) and the potential leaching to groundwater (Table 6).

\subsection{Life cycle inventory $(L C I)$ for peat}

The inventory for peat includes the four main phases of the peat life cycle (Cleary et al., 2005), as shown in Figure 2: preparation and use of peat-land, peat extraction and processing, transportation to the growth media manufacturing plant, and decomposition and environmental effects during and after use on land. The complete collection of data can be found in Boldrin \& Christensen (2008). The inventory is built with a consequential approach, where $L C l$ data for peat represent the difference between a baseline situation (undisturbed peatland) and a current situation (excavated peatland). This means that the reported emissions are considered as additional emissions occurring when excavating peat from the peatland. 
Table 6 - LCl (resource consumption, emissions to air, water and soil) for $1 \mathrm{Mg}$ of compost, originating from $2.33 \mathrm{Mg}$ of waste in case of kitchen waste compost (KWC) and from $1.48 \mathrm{Mg}$ of waste in case of garden waste compost (GWC).

\begin{tabular}{|c|c|c|c|c|c|c|c|c|c|c|}
\hline \multirow[t]{2}{*}{ Substance } & \multirow[t]{2}{*}{ type } & \multirow[t]{2}{*}{ Unit } & \multicolumn{2}{|c|}{ Composting } & \multicolumn{2}{|c|}{ Use } & \multicolumn{2}{|c|}{ Fertilizer offset } & \multicolumn{2}{|c|}{ Total } \\
\hline & & & KWC & GWC & KWC & GWC & KWC & GWC & KWC & GWC \\
\hline Electricity * & Resource & KWh & 51.3 & - & - & - & - & - & 51.3 & - \\
\hline Diesel * & Resource & 1 & - & 4.08 & - & - & - & - & - & 4.08 \\
\hline Biogenic $\mathrm{CO}_{2}$ & Air & $\mathrm{kg}$ & 353 & 607 & 339 & 336 & - & - & 692 & 944 \\
\hline Carbon Binding & Air & $\mathrm{kg}$ & - & - & 14.4 & 13.7 & - & - & 14.4 & 13.7 \\
\hline Methane $\left(\mathrm{CH}_{4}\right)$ & Air & $\mathrm{kg}$ & - & 4.5 & - & - & - & - & - & 4.5 \\
\hline Nitrous Oxide $\left(\mathrm{N}_{2} \mathrm{O}\right)$ & Air & $\mathrm{kg}$ & 0.40 & 0.01 & 0.29 & 0.26 & - & - & 0.68 & 0.27 \\
\hline Carbon Monoxide (CO) & Air & $\mathrm{kg}$ & - & 0.07 & - & - & - & - & - & 0.07 \\
\hline Ammonia $\left(\mathrm{NH}_{3}\right)$ & Air & $\mathrm{g}$ & - & 4 & 15 & 14 & - & - & 15 & 18 \\
\hline 2-Pentene (Trans) & Air & $\mathrm{g}$ & 0.60 & - & - & - & - & - & 0.60 & - \\
\hline Butoxypropylacetate & Air & $\mathrm{g}$ & 0.45 & - & - & - & - & - & 0.45 & - \\
\hline Sulphuric Acid $\left(\mathrm{H}_{2} \mathrm{SO}_{4}\right)$ & Air & $\mathrm{g}$ & 0.45 & - & - & - & - & - & 0.45 & - \\
\hline Nitrate $\left(\mathrm{NO}_{3}-\right)$ & Freshwater & $\mathrm{g}$ & - & - & 12 & 11 & - & - & 12 & 11 \\
\hline Potassium (K) & Groundwater & $\mathrm{kg}$ & - & - & 2.1 & 2.8 & - & - & 2.1 & 2.8 \\
\hline Chloride (Cl-) & Groundwater & kg & - & - & 0.99 & 1.1 & - & - & 0.99 & 1.1 \\
\hline Calcium (Ca) & Groundwater & $\mathrm{kg}$ & - & - & 1.3 & 0.38 & - & - & 1.3 & 0.38 \\
\hline Sodium (Na) & Groundwater & $\mathrm{kg}$ & - & - & 0.42 & 0.28 & - & - & 0.42 & 0.28 \\
\hline Magnesium & Groundwater & kg & - & - & 0.20 & 0.09 & - & - & 0.20 & 0.09 \\
\hline Sulphate $\left(\mathrm{SO}_{4}^{(2-)}\right)$ & Groundwater & $\mathrm{kg}$ & - & - & 0.99 & 0.07 & - & - & 0.99 & 0.07 \\
\hline Aluminum (Al) & Groundwater & $\mathrm{g}$ & - & - & 33 & 19 & - & - & 33 & 19 \\
\hline Iron (Fe) & Groundwater & $\mathrm{g}$ & - & - & 51 & 18 & - & - & 51 & 18 \\
\hline Nitrate $\left(\mathrm{NO}_{3}-\right)$ & Groundwater & $\mathrm{g}$ & - & - & 12 & 12 & - & - & 12 & 12 \\
\hline Zinc (Zn) & Groundwater & g & - & - & 4.5 & 3.1 & - & - & 4.5 & 3.1 \\
\hline Manganese (Mn) & Groundwater & $\mathrm{g}$ & - & - & 2.6 & 2.8 & - & - & 2.6 & 2.8 \\
\hline NVOC & Groundwater & g & - & - & 199 & 1.5 & - & - & 199 & 1.5 \\
\hline Arsenic (As) & Groundwater & $\mathrm{g}$ & - & - & 0.43 & 0.41 & - & - & 0.43 & 0.41 \\
\hline Copper (Cu) & Groundwater & $\mathrm{g}$ & - & - & 0.47 & 0.40 & - & - & 0.47 & 0.40 \\
\hline Lead $(\mathrm{Pb})$ & Groundwater & $\mathrm{g}$ & - & - & 0.16 & 0.19 & - & - & 0.16 & 0.19 \\
\hline Nickel (Ni) & Groundwater & $\mathrm{g}$ & - & - & 0.24 & 0.11 & - & - & 0.24 & 0.11 \\
\hline Molybdenum (Mo) & Groundwater & $\mathrm{g}$ & - & - & 0.52 & 0.10 & - & - & 0.52 & 0.10 \\
\hline Chromium (Cr) & Groundwater & $\mathrm{g}$ & - & - & 0.04 & 0.02 & - & - & 0.04 & 0.02 \\
\hline Antimony (Sb) & Groundwater & $\mathrm{g}$ & - & - & 0.08 & 0.02 & - & - & 0.08 & 0.02 \\
\hline Cadmium (Cd) & Groundwater & $\mathrm{g}$ & - & - & $2 \mathrm{e}^{-03}$ & 0.004 & - & - & $2 \mathrm{e}^{-03}$ & 0.004 \\
\hline Mercury (Hg) & Groundwater & $\mathrm{g}$ & - & - & $2 e^{-06}$ & 0.002 & - & - & $2 e^{-06}$ & 0.002 \\
\hline Aluminum (Al) & Soil & $\mathrm{kg}$ & - & - & 7.3 & 16 & - & - & 7.3 & 16 \\
\hline Iron (Fe) & Soil & kg & - & - & 9.3 & 8.3 & - & - & 9.3 & 8.3 \\
\hline Manganese (Mn) & Soil & $\mathrm{g}$ & - & - & 231 & 213 & - & - & 231 & 213 \\
\hline Zinc (Zn) & Soil & $\mathrm{g}$ & - & - & 195 & 96 & - & - & 195 & 96 \\
\hline Copper (Cu) & Soil & g & - & - & 68 & 23 & - & - & 68 & 23 \\
\hline Lead (Pb) & Soil & g & - & - & 13.8 & 22 & - & - & 13.8 & 22 \\
\hline Chromium (Cr) & Soil & $\mathrm{g}$ & - & - & 9.2 & 18 & - & - & 9.2 & 18 \\
\hline Nickel (Ni) & Soil & $\mathrm{g}$ & - & - & 6.6 & 4.5 & - & - & 6.6 & 4.5 \\
\hline Molybdenum (Mo) & Soil & g & - & - & 1.5 & 2.6 & - & - & 1.5 & 2.6 \\
\hline Arsenic (As) & Soil & $\mathrm{g}$ & - & - & 2.9 & 2.0 & - & - & 2.9 & 2.0 \\
\hline Cadmium (Cd) & Soil & $\mathrm{g}$ & - & - & 0.31 & 0.24 & - & - & 0.31 & 0.24 \\
\hline Mercury (Hg) & Soil & $\mathrm{g}$ & - & - & 0.27 & 0.09 & - & - & 0.27 & 0.09 \\
\hline Antimony (Sb) & Soil & g & - & - & 0.03 & 0.03 & - & - & 0.03 & 0.03 \\
\hline $\mathrm{N}$ mineral fertilizer $*$ & Res. offset & $\mathrm{kg}$ & - & - & - & - & 1.2 & 1.1 & 1.2 & 1.1 \\
\hline K mineral fertilizer * & Res. offset & $\mathrm{kg}$ & - & - & - & - & 5.7 & 10.8 & 5.7 & 10.8 \\
\hline P mineral fertilizer * & Res. offset & $\mathrm{kg}$ & - & - & - & - & 4.7 & 1.08 & 4.7 & 1.1 \\
\hline
\end{tabular}




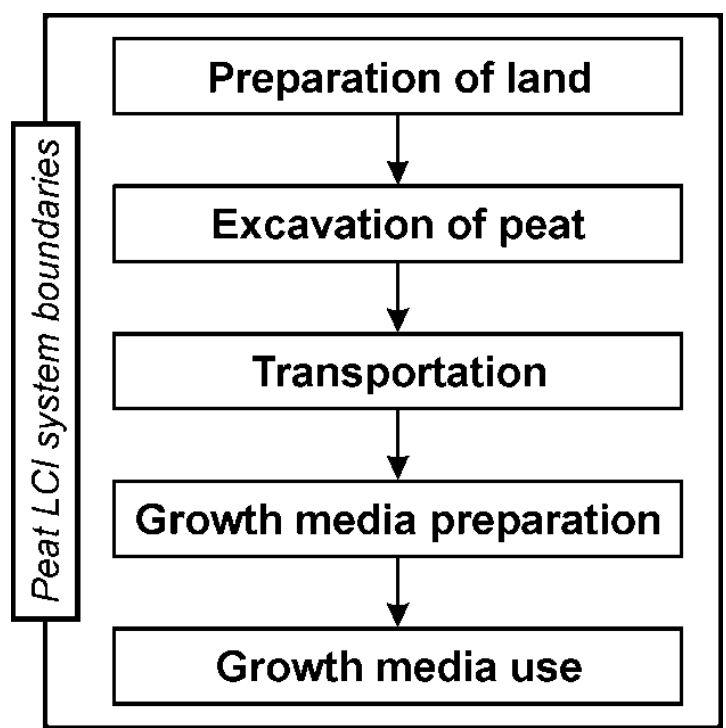

Figure 2 - LCl system boundaries for peat.

Before harvesting, the peatland is dried, cleared of vegetation and levelled. The inventory accounts for alteration of the net GHG emissions during this phase, as calculated in Cleary et al. (2005).

Extraction and processing is performed by means of fossil-fuelled heavy machineries. Emissions (runoff) to water of eutrophying pollutants could occur during this phase. Therefore, the inventory includes air emissions during production and combustion of fuel and emissions of organic matter, nitrogen and phosphorous nutrients, and soluble metals to watercourses (Koskela et al., 2004; Cleary et al., 2005). Being produced mainly at northern latitudes, peat is often transported for long distances with different transportation means. The inventory includes air emissions from production and combustion of fossil fuel used for transportation. Amounts and provenience of peat used in Denmark have been calculated for 2006, using data from Statistics Danmark. In average, it was estimated that peat is transported for $500 \mathrm{~km}$ by ship, $120 \mathrm{~km}$ by train, $110 \mathrm{~km}$ by lorry in highways and $50 \mathrm{~km}$ on local roads. The complete dataset can be found in Boldrin \& Christensen (2008).

When used on land, peat decomposes and may release some pollutants. The inventory includes emissions to air of all the fossil carbon content of peat and leaching to groundwater of different substances. Peat $\mathrm{LCl}$ is presented in Table 7. Leaching of substances to groundwater is calculated according to the leachate composition reported in Table 4. Emissions to soil are calculated as done for compost. Peat-based growth media are often used for indoor horticulture and the generated leachate is collected and recirculated. Such a case could be studied by excluding leaching values in Table 6 from the $\mathrm{LCl}$ of peat. 
Table 7 - LCl for $1 \mathrm{Mg}$ of peat (resource consumption, emissions to air, soil and water).

\begin{tabular}{|c|c|c|c|c|c|c|c|}
\hline Substance & type & Unit & $\begin{array}{l}\text { Preparation and } \\
\text { use of peatland }\end{array}$ & Production & Transportation & $\begin{array}{l}\text { Use on } \\
\text { land }\end{array}$ & Total \\
\hline Peat & Resource & $\mathrm{kg}$ & - & - & - & - & 1000 \\
\hline Diesel & Resource & $\mathrm{kg}$ & - & 5.7 & 3.7 & - & 9.4 \\
\hline LPG & Resource & $\mathrm{kg}$ & - & 2.1 & - & - & 2.1 \\
\hline Gasoline & Resource & $\mathrm{kg}$ & - & 0.73 & - & - & 0.73 \\
\hline Light fuel oil & Resource & $\mathrm{kg}$ & - & 0.02 & - & - & 0.02 \\
\hline Natural gas & Resource & $\mathrm{kg}$ & - & $3.69 \mathrm{e}^{-06}$ & - & - & $3.7 e^{-06}$ \\
\hline $\mathrm{CO}_{2}$ fossil & Air & $\mathrm{kg}$ & 108 & 34 & 12 & 815 & 969 \\
\hline $\mathrm{NO}_{\mathrm{x}}$ & Air & $\mathrm{kg}$ & - & 0.48 & 0.21 & - & 0.68 \\
\hline $\mathrm{CH}_{4}$ & Air & g & 197 & 1.8 & - & - & 199 \\
\hline $\mathrm{N}_{2} \mathrm{O}$ & Air & $\mathrm{g}$ & - & 14 & - & - & 14 \\
\hline CO & Air & $\mathrm{g}$ & - & 171 & 27 & - & 198 \\
\hline $\mathrm{HC}$ & Air & $\mathrm{g}$ & - & 70 & - & - & 70 \\
\hline Partic. & Air & $\mathrm{g}$ & - & 50 & 7.1 & - & 57 \\
\hline $\mathrm{SO}_{2}$ & Air & $\mathrm{g}$ & - & 38 & - & - & 38 \\
\hline voc & Air & $\mathrm{g}$ & - & - & 21 & - & 21 \\
\hline $\mathrm{Cr}$ & Air & $\mathrm{g}$ & - & - & $1.8 \mathrm{e}^{-04}$ & - & $1.8 \mathrm{e}^{-04}$ \\
\hline $\mathrm{Cu}$ & Air & $\mathrm{g}$ & - & - & $3.7 e^{-04}$ & - & $3.7 e^{-04}$ \\
\hline $\mathrm{Hg}$ & Air & $\mathrm{g}$ & - & - & $3.7 e^{-06}$ & - & $3.7 e^{-06}$ \\
\hline Cd & Air & $\mathrm{g}$ & - & - & $3.7 e^{-05}$ & - & $3.7 e^{-05}$ \\
\hline $\mathrm{Pb}$ & Air & g & - & - & $3.7 e^{-04}$ & - & $3.7 e^{-04}$ \\
\hline $\mathrm{Ni}$ & Air & $\mathrm{g}$ & - & - & $3.7 e^{-03}$ & - & $3.7 e^{-03}$ \\
\hline Se & Air & $\mathrm{g}$ & - & - & $3.7 e^{-05}$ & - & $3.7 e^{-05}$ \\
\hline $\mathrm{Zn}$ & Air & $\mathrm{g}$ & - & - & $3.7 e^{-03}$ & - & $3.7 e^{-03}$ \\
\hline Org. matter & Water & $\mathrm{kg}$ & - & 3.0 & - & - & 3.0 \\
\hline $\mathrm{COD}_{\mathrm{Mn}}$ & Water & $\mathrm{kg}$ & - & 1.8 & - & - & 1.8 \\
\hline Susp. solids & Water & $\mathrm{kg}$ & - & 1.7 & - & - & 1.7 \\
\hline Nitrogen & Water & $\mathrm{g}$ & - & 180 & - & - & 180 \\
\hline $\mathrm{NH}_{4}-\mathrm{N}$ & Water & $\mathrm{g}$ & - & 86 & - & - & 86 \\
\hline Phosphorus & Water & $\mathrm{g}$ & - & 5.8 & - & - & 5.8 \\
\hline Sodium (Na) & Groundwater & $\mathrm{g}$ & - & - & - & 26 & 26 \\
\hline Chloride (Cl-) & Groundwater & $\mathrm{g}$ & - & - & - & 23 & 23 \\
\hline Potassium (K) & Groundwater & $\mathrm{g}$ & - & - & - & 6.7 & 6.7 \\
\hline Calcium (Ca) & Groundwater & $\mathrm{g}$ & - & - & - & 6.3 & 6.3 \\
\hline Sulphate (SO4(2-)) & Groundwater & $\mathrm{g}$ & - & - & - & 5.9 & 5.9 \\
\hline Nitrate (NO3-) & Groundwater & g & - & - & - & 5.7 & 5.7 \\
\hline Magnesium & Groundwater & $\mathrm{g}$ & - & - & - & 5.5 & 5.5 \\
\hline Zinc (Zn) & Groundwater & $\mathrm{g}$ & - & - & - & 1.3 & 1.3 \\
\hline Iron (Fe) & Groundwater & $\mathrm{g}$ & - & - & - & 0.68 & 0.68 \\
\hline Aluminum (AI) & Groundwater & $\mathrm{g}$ & - & - & - & 0.64 & 0.64 \\
\hline NVOC & Groundwater & $\mathrm{g}$ & - & - & - & 0.44 & 0.44 \\
\hline Manganese (Mn) & Groundwater & $\mathrm{g}$ & - & - & - & 0.06 & 0.06 \\
\hline Nickel (Ni) & Groundwater & g & - & - & - & 0.008 & 0.008 \\
\hline Lead $(\mathrm{Pb})$ & Groundwater & $\mathrm{g}$ & - & - & - & 0.007 & 0.007 \\
\hline Arsenic (As) & Groundwater & $\mathrm{g}$ & - & - & - & 0.007 & 0.007 \\
\hline Copper (Cu) & Groundwater & $\mathrm{g}$ & - & - & - & 0.004 & 0.004 \\
\hline Chromium (Cr) & Groundwater & $\mathrm{g}$ & - & - & - & 0.002 & 0.002 \\
\hline Molybdenum (mo) & Groundwater & $\mathrm{g}$ & - & - & - & 0.001 & 0.001 \\
\hline Mercury (Hg) & Groundwater & $\mathrm{g}$ & - & - & - & $6 e^{-04}$ & $6 e^{-04}$ \\
\hline Cadmium (Cd) & Groundwater & g & - & - & - & $4 e^{-04}$ & $4 e^{-04}$ \\
\hline Antimony (Sb) & Groundwater & $\mathrm{g}$ & - & - & - & $3 e^{-04}$ & $3 e^{-04}$ \\
\hline Aluminum (AI) & Soil & $\mathrm{g}$ & - & - & - & 177 & 177 \\
\hline Iron (Fe) & Soil & g & - & - & - & 126 & 126 \\
\hline Manganese (Mn) & Soil & $\mathrm{g}$ & - & - & - & 2.4 & 2.4 \\
\hline Lead $(\mathrm{Pb})$ & Soil & $\mathrm{g}$ & - & - & - & 1.2 & 1.2 \\
\hline Chromium (Cr) & Soil & $\mathrm{g}$ & - & - & - & 0.22 & 0.22 \\
\hline Copper (Cu) & Soil & $\mathrm{g}$ & - & - & - & 0.21 & 0.21 \\
\hline Arsenic (As) & Soil & $\mathrm{g}$ & - & - & - & 0.10 & 0.10 \\
\hline Nickel (Ni) & Soil & $\mathrm{g}$ & - & - & - & 0.09 & 0.09 \\
\hline Zinc (Zn) & Soil & $\mathrm{g}$ & - & - & - & 0.04 & 0.04 \\
\hline Molybdenum (Mo) & Soil & $\mathrm{g}$ & - & - & - & 0.03 & 0.03 \\
\hline Antimony (Sb) & Soil & $\mathrm{g}$ & - & - & - & 0.02 & 0.02 \\
\hline Cadmium (Cd) & Soil & $\mathrm{g}$ & - & - & - & 0.02 & 0.02 \\
\hline Mercury (Hg) & Soil & $\mathrm{g}$ & - & - & - & 0.01 & 0.01 \\
\hline
\end{tabular}




\section{4. $\mathrm{LCl}$ comparison}

Dilution of peat with compost could be done at different ratios (up to 50\%, Prasad \& Maher, 2006), depending on the type of compost and the desired characteristics of the growth media. The substitution is done on a 1:1 volume basis (Mathur \& Voisin, 1996). The inventories presented in Table 6 and Table 7 have been compared, using as a reference $1 \mathrm{Mg}$ of compost and an equivalent volume of peat, used as bulking components in preparation of enriched growth media to be used on land. Densities of compost and peat reported in Table 2 have been used to convert volumes into masses. The life cycle inventory boundaries for compost and peat are presented in Figure 1 and Figure 2. Compost is presented in two alternative scenarios, depending on the type of waste (i.e. green waste or garden waste) that it is produced from. The reason for including mineral fertilizers offsetting in the compost system boundaries is twofold. First, the assessment can focus on the material (compost, peat) rather than on the growth media. Second, the peat $\mathrm{LCl}$ remains the same no matter the type of compost it is compared to. In fact, including mineral fertilizers in the peat life cycle would have required definition of two different inventories for peat, depending on the nutrient content of the compost that the peat was compared to. Environmental loads from the technical processes of growth media preparation are not calculated, as it is assumed to be the same in both scenarios and therefore could be left out according to the consequential LCA principles.

Figure 3 presents results for the normalised potential non-toxic impacts. Composts (both green and garden waste) have better environmental performances in three out of four categories. Figure 4 presents contributions to Global Warming category from different gases, expressed in $\mathrm{kg} \mathrm{CO}_{2}$-eq. Peat has a large emission of "fossil" - $\mathrm{CO}_{2}$, while compost is only generating biogenic- $\mathrm{CO}_{2}$, which is neutral (GWP $=0$ ) with respect to global warming (Christensen et al., 2009). Savings of using compost instead of peat are estimated to be $69 \mathrm{~kg} \mathrm{CO}$-eq. $\mathrm{Mg}^{-1}$ of green waste and $148 \mathrm{~kg} \mathrm{CO}_{2}$ eq. $\mathrm{Mg}^{-1}$ of garden waste. $\mathrm{N}_{2} \mathrm{O}$ formation from use of compost is a relevant potential contributor to global warming. Values used (see Table 5) for $\mathrm{N}_{2} \mathrm{O}$ formation are quite precautionary, so in different situations impact on global warming could be expected to be lower than those presented in Figure 3 and 4. Taking into account $\mathrm{N}_{2} \mathrm{O}$ emissions during composting process is the reason for lower GHG savings estimated in this study, compared to other studies (e.g. Kranert \& Gottschall, 2007) where this factor has not been taken into account. 


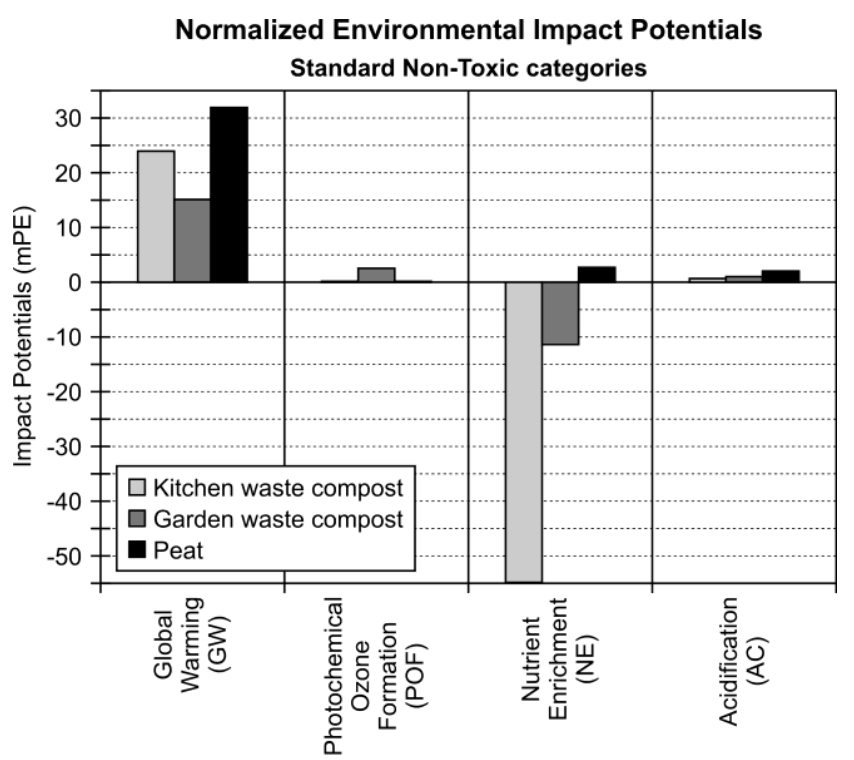

Figure 3 - Potential non-toxic impacts from use of compost $(1 \mathrm{Mg})$ and peat $(285 \mathrm{~kg})$ as bulking materials in growth media preparation.

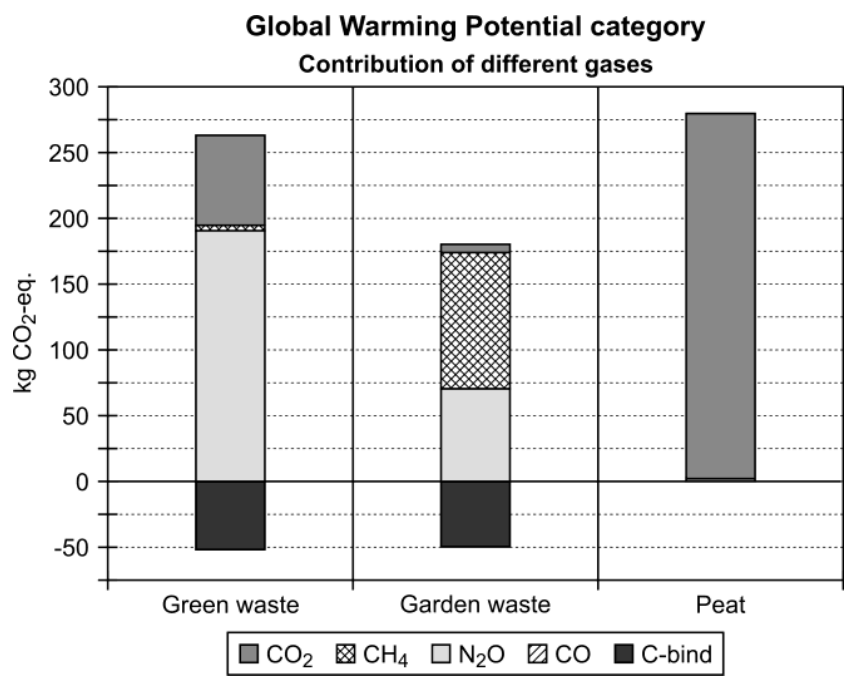

Figure 4 - Contribution of different gases to Global Warming Potential.

Large savings in terms of nutrient enrichment (eutrophication) for compost are mainly due to the replacement of phosphorous fertilizer. In fact, during the production of commercial $\mathrm{P}$ fertilizers, consistent amounts of phosphate are discharged into freshwater, contributing to eutrophication. Potential detrimental effects of peat on nutrient enrichment and acidification are mainly due to emissions of $\mathrm{NO}_{\mathrm{x}}$ from the combustion of fossil fuels in heavy machineries (e.g. for excavation) and transportation means. Potential impacts on Photochemical Ozone Formation (Smog) are quite small. Garden waste compost has the most detrimental effect in this category, mainly because of the methane emissions from the windrows. Methane is a potential precursor of smog formation.

Figure 5 presents results for the normalised potential toxic impacts. The graph should be considered as a qualitative assessment rather quantitative, meaning that the three options can be compared within one category, but categories should not be compared to each other in an attempt to estimate the overall impact. Harmonization of the toxicity characterization factors as well as a consensus on how to normalise and 
aggregate the individual impacts are still needed and under debate (Christensen et al., 2007). Compost performs worse than peat in Human Toxicity via Water and Human Toxicity via Soil because of the higher content of heavy metals. Kitchen waste compost has a larger impact on Human Toxicity via Water than garden waste compost because of the higher content of mercury (Table 2), which is the main contributor to this impact category. Arsenic (As), chromium $(\mathrm{Cr})$ and mercury $(\mathrm{Hg})$ are the main contributors to Human Toxicity via Soil for both types of compost. The larger environmental load attributed to garden waste compost is due to the higher content of chromium as can be seen in Table 2. Green waste compost has a potential beneficial effect with regards to ecotoxicity in water due to the avoided emissions of $\mathrm{Cd}$ associated with $\mathrm{P}$ fertilizer.

The impact category called spoiled groundwater resources is directly related to the leaching properties of the materials. The higher load of metals in leachate (Table 4) results in a bigger impact for compost.

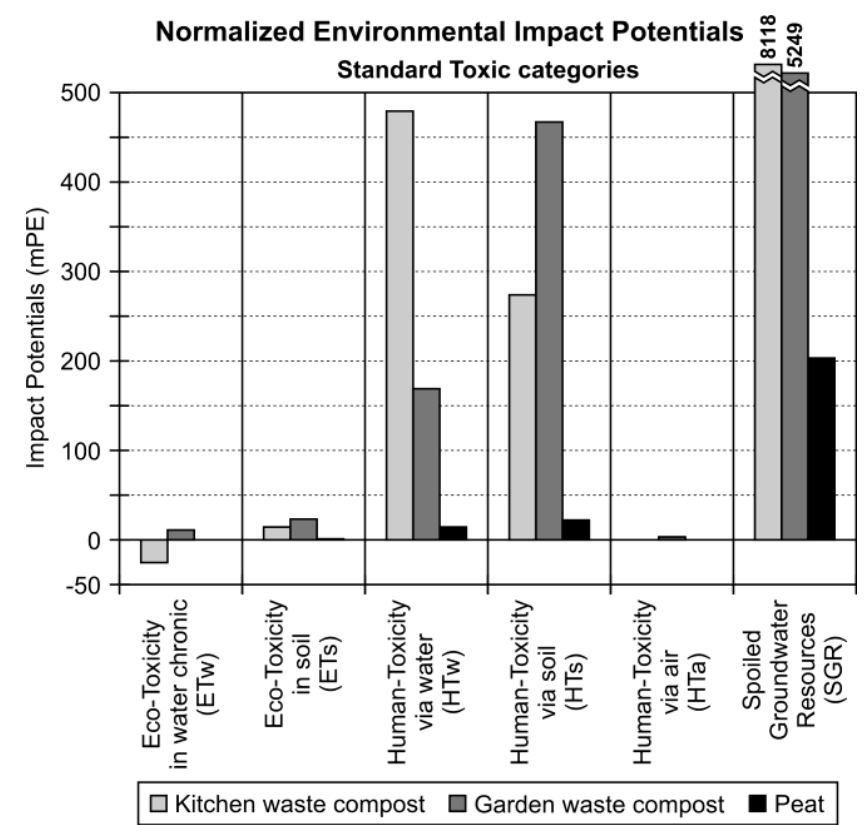

Figure 5 - Potential toxic impacts from use of compost $(1 \mathrm{Mg})$ and peat $(285 \mathrm{~kg})$ as bulking materials in growth media preparation.

\subsection{Uncertainty and sensitivity analysis}

Uncertainty important analysis (Björklund, 2002) was carried out to determine how the uncertainty is related to different factors. This kind of analysis includes an assessment of the relevance of different parameters on the results, an evaluation of their uncertainty, and a sensitivity test.

A number of parameters were selected and their relevance (Table 9, second column) on the results was determined based on the results previously presented (Figures 3 to 5). The uncertainty related to each factor/parameter was qualitatively evaluated:

- Densities of compost and peat can fluctuate quite relevantly (Table 2), determining important variations in the peat compost substitution ratio, which is therefore considered highly uncertain. 
- Electricity requirements for tunnel composting. According to Boldrin et al. (2009), the used data is an average value for this type of composting technology. The uncertainty is considered medium.

- Carbon binding within 100 years time horizon. It depends on local conditions, such as soil type, climate, farming practices, etc. The value used in the $\mathrm{LCl}$ is in the high end of the range modelled by Bruun et al. (2006) and its uncertainty is thus considered medium.

- Methane emissions from garden waste compost. The data used is in the typical range reported in literature (Boldrin et al., 2009). The uncertainty is considered low.

- Methane emissions from peat. The data used originate from literature. The uncertainty is precautionarily considered high.

- Chemical composition of peat and compost. Determined by means of chemical analysis. Standard deviation is small for most parameters. The uncertainty is considered low.

- Leaching properties of peat and compost. Determined by means of leaching test. Results (Table 4) show that variation across samples is in some case relevant. The uncertainty is considered medium.

A number of other factors/parameters were not tested in the uncertainty analysis. The reason for that is either their small influence on the results or the fact that varying these values would enlarge the differences shown by the results, thereby strengthening the conclusions:

- Emissions of $\mathrm{N}_{2} \mathrm{O}$. The emission factor for $\mathrm{N}_{2} \mathrm{O}$ during compost degradation was chosen in a precautionary perspective and in reality it is expected to be lower than what previously used. Thus, from a global warming perspective, the benefits of using compost instead of peat are expected to be even bigger than presented in the results.

- Transportation of peat. Transportation of peat from the excavation site to the market has been estimated considering commercial flows of peat to and from Denmark. Precise data were not available, but the results show that transportation contributes marginally to the environmental footprint of peat.

- Energy requirement for garden waste composting. The used datum can be considered as a typical value (Boldrin et al., 2009). Furthermore, results show that energy consumption has a marginal influence on the results.

A sensitivity test, aiming to determine how a result is influenced by a parameter, was performed by varying the different parameters in selected scenarios, according to Table 8. The quantitative results of the test are shown graphically in Figure 6 and Figure 7 by means of variation intervals, showing the consequences of the changes mentioned. A qualitative indicator describing the sensitivity of each parameter relative to the different impact categories was then defined according to the following considerations. For a specific impact category, high sensitivity was assigned if the variation interval was large relatively to the impact in itself or if the variation interval was larger than the absolute (numerical) difference found between the analysed scenarios. The results are reported in Table 9. 
Table 8 - Sensitivity test for different parameters and scenarios.

\begin{tabular}{|c|c|c|c|c|c|c|}
\hline Test name & Tested scenario & Parameter changed & Change & From & & \\
\hline Substitution factor & Peat & $\begin{array}{l}\text { Compost/peat } \\
\text { substitution factor }\end{array}$ & $\pm 25 \%$ & $285 \mathrm{~kg}$ & $214 \mathrm{~kg}$ & $356 \mathrm{~kg}$ \\
\hline Electricity requirements & KW compost & Electricity use & $\pm 50 \%$ & 51 kWh & $26 \mathrm{kWh}$ & 76 kWh \\
\hline Carbon binding & $\mathrm{KW}$ compost & Carbon binding & $-50 \% *$ & $14 \%$ & $7 \%$ & - \\
\hline Methane from GW & GW compost & Methane emission & $\pm 50 \%$ & $2 \%$ & $1 \%$ & $3 \%$ \\
\hline Methane from peat & Peat & Methane emission & $\pm 50 \%$ & $199 \mathrm{~g} / \mathrm{Mg}$ & $100 \mathrm{~g} / \mathrm{Mg}$ & $300 \mathrm{~g} / \mathrm{Mg}$ \\
\hline Chemical comp. GW & GW compost & Chemical composition & \pm St.dev. & Table 3 & Table 3 & Table 3 \\
\hline Chemical comp. peat & Peat & Chemical composition & \pm St.dev. & Table 3 & Table 3 & Table 3 \\
\hline Leaching GW & GW compost & Leachate composition & \pm St.dev. & Table 4 & Table 4 & Table 4 \\
\hline Leaching peat & Peat & Leachate composition & \pm St.dev. & Table 4 & Table 4 & Table 4 \\
\hline
\end{tabular}

Table 9-Qualitative results of the uncertainty importance analysis.

\begin{tabular}{lccc}
\hline Parameter & Relevance on the results & Uncertainty & Sensitivity \\
\hline Substitution factor & High & High & High \\
Electricity requirements & Low & Medium & Low \\
Carbon binding & Medium & Medium & Low \\
Methane from GW & High & Low & Low \\
Methane from peat & Low & High & Low \\
Chemical comp. GW & Medium & Low & Medium \\
Chemical comp. peat & Low & Low & Low \\
Leaching GW & Medium & Medium & Low \\
Leaching peat & Medium & Medium & Low \\
\hline
\end{tabular}

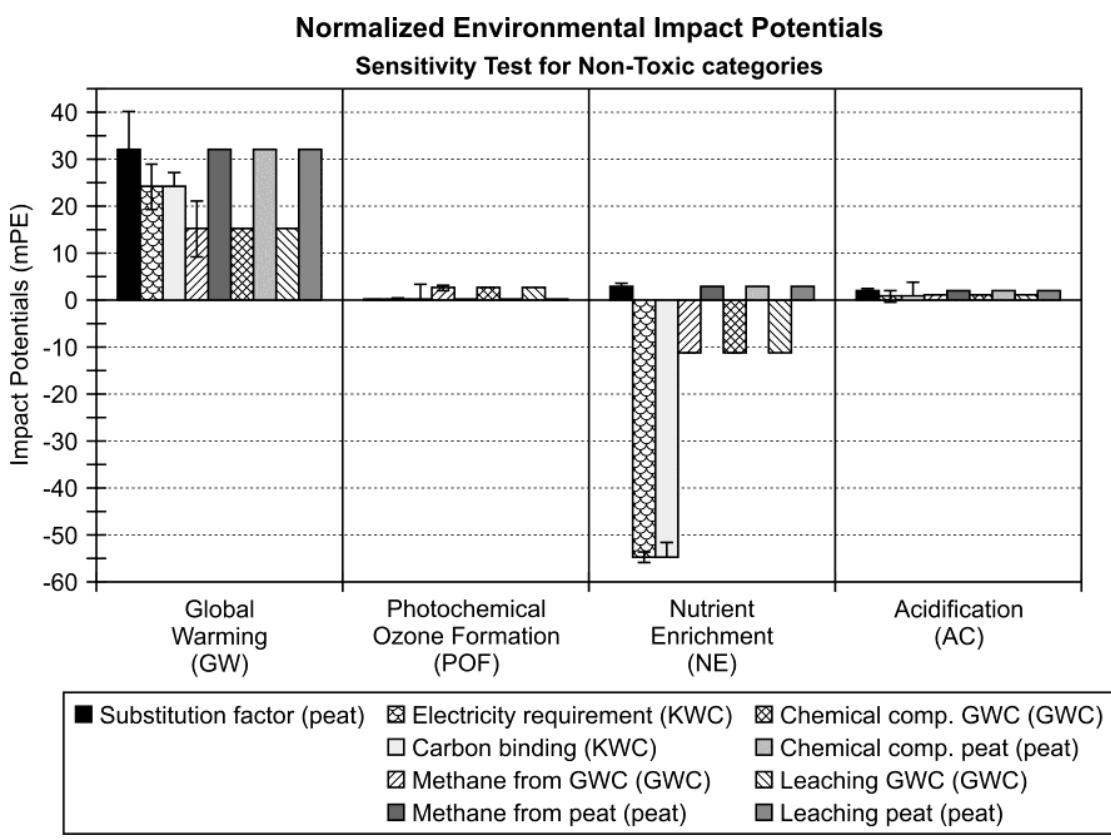

Figure 6 - Results of the sensitivity test for non-toxic impact categories. 


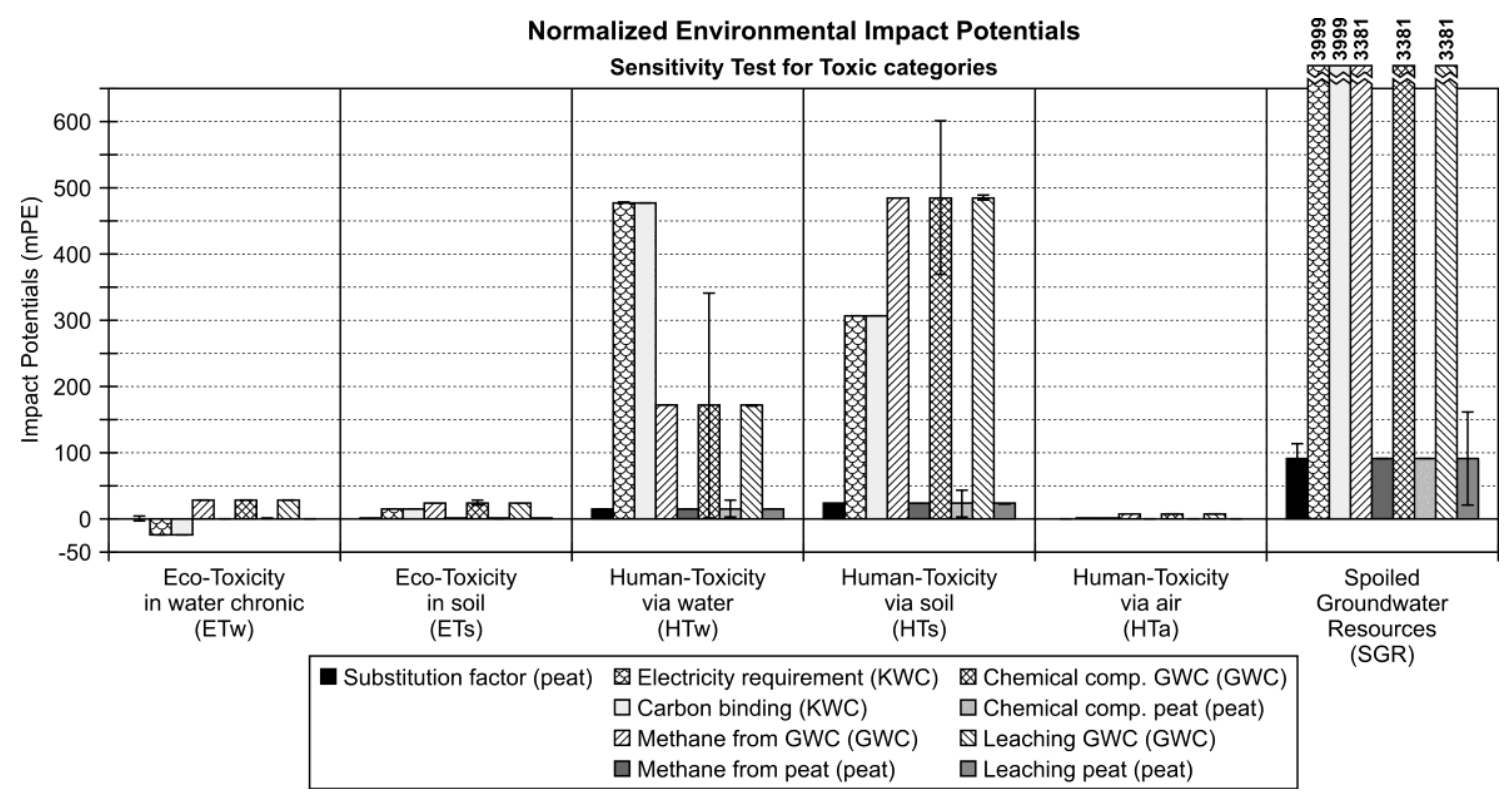

Figure 7 - Results of the sensitivity test for toxic impact categories.

The qualitative results of the uncertainty analysis are shown in Table 9 and they indicate that the most problematic parameter is the substitution factor between compost and peat. Some uncertainty is also introduced in the modelling by the chemical composition of garden waste - mainly due to variability in $\mathrm{Hg}$ content affecting human toxicities and spoiled groundwater impact categories. However, the results also reveal that the conclusions of the assessment might not be altered, because in most of the cases the differences seen between scenarios are larger than the uncertainty related to the results.

\subsection{An illustrative example}

According to consequential LCA principles, the system boundaries of peat should be expanded to include an alternative option for handling of organic waste (Finnveden, 1999; Ekvall \& Weidema, 2004). In fact, composting functions primarily as a waste managing service and the peat scenario should therefore consider the consequences of not using compost in growth media (i.e. compost is used for other purposes or the organic waste is treated in a different way). System expansion was not included in the LCls and in the comparison of them, because of the variety of possible alternative treatments for the organic waste. The LCls are as tables the main out-come of the study and can be used when performing LCA studies where local specific situations are analysed in detail against local alternatives.

An hypothetical case including two scenarios have been developed to show the use of the presented inventories and the consequences of implementing consequential LCA principles. In the "green waste" scenario, $1 \mathrm{Mg}$ of green waste is composted and the produced compost is used in substitution of peat during preparation of growth media (mineral offsetting is included). The inventories for the different processes were obtained are the above-presented inventories. In the "peat" scenario, $1 \mathrm{Mg}$ is landfilled in a conventional landfill (bottom liner, leachate collection system, leachate treatment, gas collection system, soil topcover) with energy recovery ( $40 \%$ of the generated gas is collected and sent to CHP, where the produced energy substitutes $100 \%$ for energy production at a coal-fired power plant), while the growth media is 
produced by using peat. In both scenarios, the environmental consequences of the use of growth media are modelled. The boundaries of the compared scenarios are presented in Figure 8 and Figure 9.

The results of the hypothetical case are shown in Figure 10 with respect to the non-toxic impact categories and in Figure 11 for the toxic impact categories. For most of the impact categories, the results show that the scenario based on composting of green waste is preferable to the scenario where green waste is landfilled and growth media are produced using peat materials, thus strengthening the conclusions previously drawn. Along with the benefits described during the LCls comparison, avoiding landfilling of organic waste results in important benefits with respect to spoiled groundwater resources.

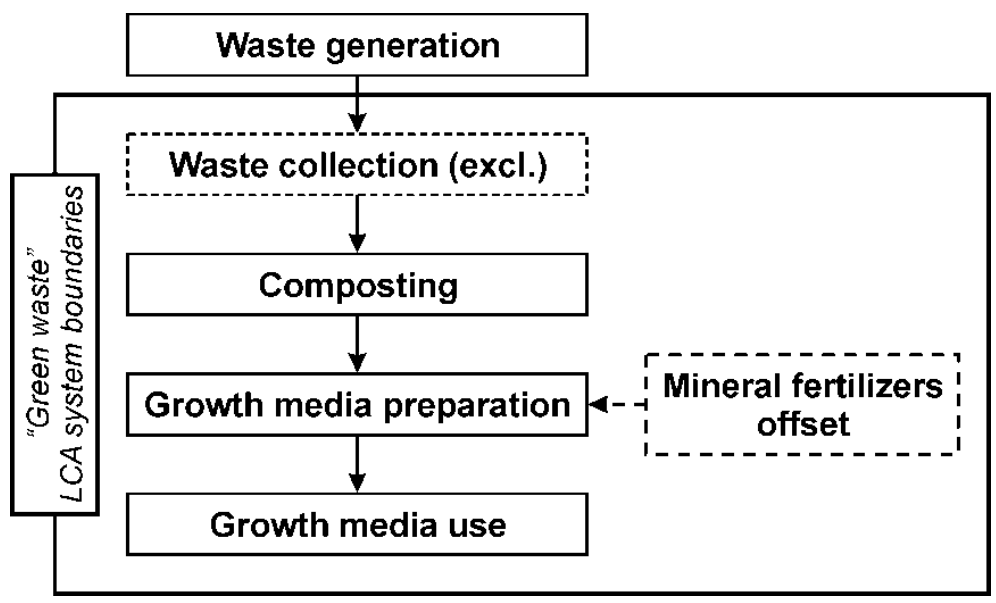

Figure 8 - "Green waste" scenario system boundaries.

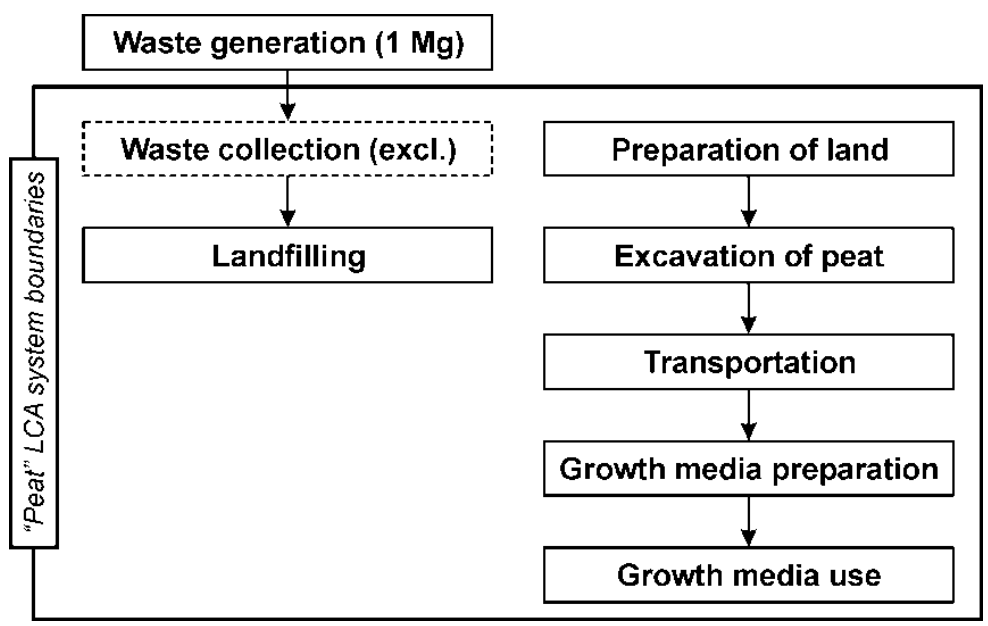

Figure 9 - "Peat" scenario system boundaries. 


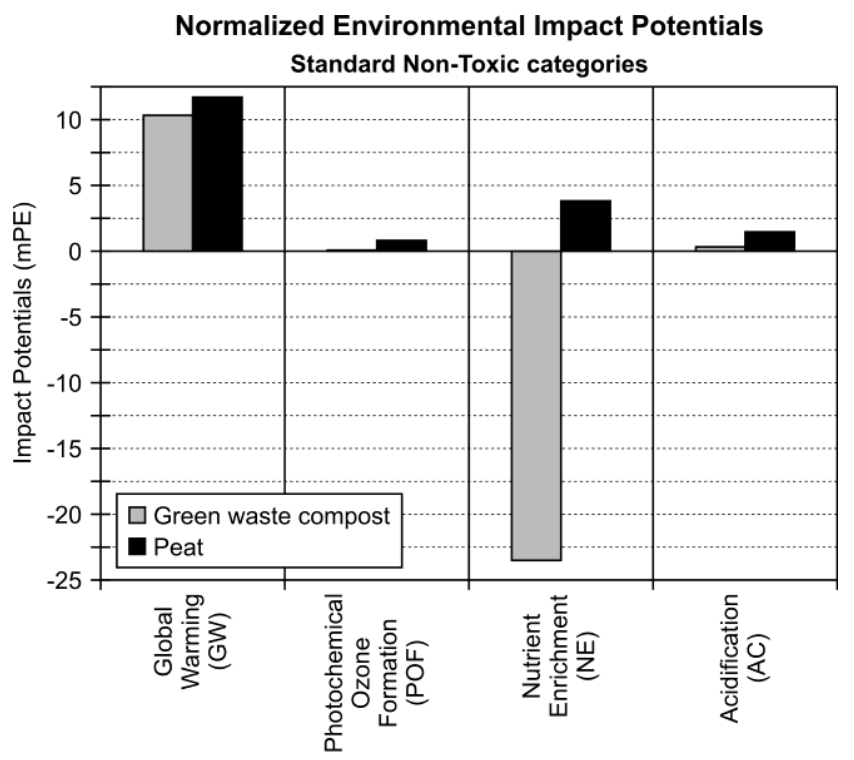

Figure 10 - Potential non-toxic impacts from the hypothetical scenarios.

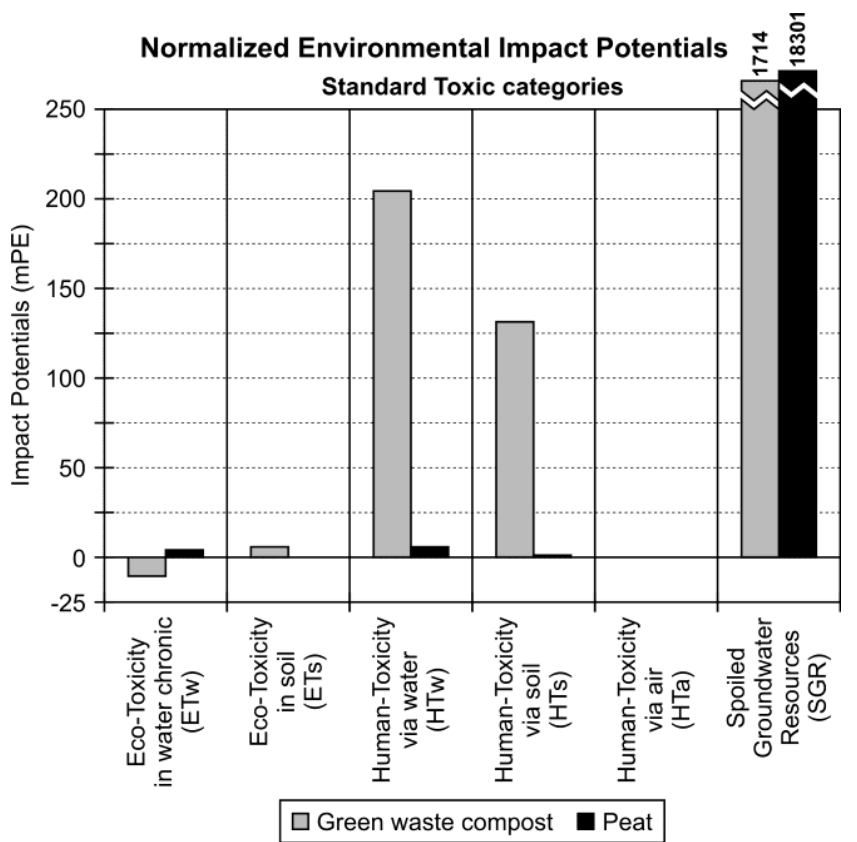

Figure 11 - Potential toxic impacts from the hypothetical scenarios.

\section{Conclusion}

The substitution of peat with compost in growth media has some potential environmental benefits. Compost has a lower impact on global warming because of the biogenic origin of the carbon contained. The savings are in the order of 9-17 mPE $\mathrm{Mg}^{-1}$ compost corresponding to $70-150 \mathrm{~kg} \mathrm{CO}$-eq. $\mathrm{Mg}^{-1}$. Further relevant improvements could be achieved by:

- reducing methane emissions from windrows by proper management;

- increasing energy efficiency in the composting plant;

- reducing $\mathrm{N}_{2} \mathrm{O}$ from use on land ( although it is not clear how).

$\mathrm{NO}_{\mathrm{x}}$ emissions from use of heavy machineries during peat excavation are prevented, with benefits in terms of eutrophication and acidification.

Compost has also a potential for substituting commercial mineral fertilizers, with consequent benefits on eutrophication in the order of $14-57 \mathrm{mPE} \mathrm{Mg}^{-1}$ compost. 
It was found that especially avoiding the productions of $\mathrm{N}$ and $\mathrm{P}$ fertilizers have a big impact on the environment. Potential impacts from compost could come from its content of heavy metals, which could either leach to groundwater or accumulate in soil (especially with repeated application, Amlinger et al., 2004).

\section{References}

Amlinger, F.; Favoino, E.; Pollak, M.; Peyr, S.; Centemero, M. and Caima, V., 2004. Heavy metals and organic compounds from wastes used as organic fertilisers. Study on behalf of the European Commission, Directorate-General Environment, accessed March 2009 from:

http://ec.europa.eu/environment/waste/compost/pdf/hm finalreport.pdf.

Andersen, J.K.; Boldrin, A.; Samuelsson, J.; Christensen, T.H. and Scheutz, C., 2009. Quantification of GHG emissions from windrow composting of garden waste. J. Env. Qual. (In press).

Boldrin, A. and Christensen, T.H., 2008. Life Cycle Inventory of peat in Denmark. Manuscript. Not published.

Boldrin, A.; Andersen, J.K.; Møller, M.; Favoino, E. and Christensen, T.H., 2009. Composting and compost utilization: accounting of greenhouse gases and global warming contributions. Waste Manag. Res., 27: 800-812.

Bruun, S.; Hansen, T.L.; Christensen, T.H.; Magid, J. and Jensen, L.S., 2006. Application of processed organic municipal solid waste on agricultural land - a scenario analysis. Env. Mod. Assess., 11: 251-265.

Christensen, T.H.; Gentil, E.; Boldrin, A.; Larsen, A.W.; Weidema, B.P. and Haushild, M.Z., 2009. $C$ balance, carbon dioxide emissions and global warming potentials in LCAmodeling of waste management systems. Waste Manag. Res., 27: 707-715.

Christensen, T.H.; Bhander, G.S.; Lindvall, H.K.; Larsen, A.W.; Fruergaard, T.H.; Damgaard, A.; Manfredi, S.; Boldrin, A.; Riber, C. and Hauschild, M.Z, 2007. Experience with the use of LCA-modelling (EASEWASTE) in waste management. Waste Manag. Res., 25: 257-262.

Cleary, J., Roulet, N.T. and Moore, T.R., 2005. Greenhouse Gas Emissions from Canadian Peat Extraction, 1990-2000: A Life-cycle Analysis. Ambio, 34: 456-461.

EASEWASTE database (2008). Database of EASEWASTE 2008, Version 4:5:001. Department of Environmental Engineering, Technical University of Denmark, Kgs. Lyngby, Denmark.

Ekvall, T. and Weidema, B.P., 2004. System boundaries and input data in consequential life cycle inventory analysis. Int J Life Cycle Assess 9(3): 161-171 
Finnveden G. 1999. Methodological aspects of life cycle assessment of integrated solid waste management systems. Resour Conserv Recycl 25(3): 173-187

Gorham E. 1991. Northern Peatlands: Role in the Carbon Cycle and Probable Responses to Climatic Warming, Ecol. Appl., 1(2): 182-195.

Hansen, T.L.; Bhander, G.S.; Christensen, T.H., Bruun, S. and Jensen, L.S., 2006. Life cycle modelling of environmental impacts from application of processed organic municipal solid waste on agricultural land (EASEWASTE). Waste Manag. Res., 24: 153166.

IPCC. 2003. Good Practice Guidance for Land Use, Land-Use Change and Forestry. Inter-governmental Panel on Climate Change (IPCC), Geneva.

IPS, 2007. International Peat Society Annual Report 2007. Accessed November 2009 from: http://www.peatsociety.org/user_files/files/Peatlands\%20International\%2012008.pdf

Joosten, H. and Clarke, D., 2002. Wise Use of Mires and Peatlands, International Mire Conservation Group and International Peat Society, Saarijärvi, Finland.

Kirkeby, J.T.; Hansen, T.L.; Birgisdóttir, H.; Bhander, G.S.; Hauschild, M.Z. and Christensen, T.H., 2006. Environmental assessment of solid waste systems and technologies: EASEWASTE. Waste Manag. Res., 24: 3-15.

Koskela, S. (ed.), 2004. Environmental analysis and indicators for the Kymenlaakso region. Documentation report 1 of the ECOREG project. Finnish Environment Institute, Helsinki.

Kranert, M. and Gottschall, R., 2007. Grünabfälle - besser kompostieren oder energetisch verwerten? EdDE-Dokumentation Nr. 11, Entsorgergemeinschaft der Deutschen Entsorgungswirtschaft e.V., Köln, Germany.

Lappalainen, E. 1996. Global Peat Resources, International Peat Society. Jyskä, Finland, 1996.

Lappi, S. and Byrne, K.A., 2004. Greenhouse Gas Budgets of Peat Use for Energy in Ireland, IEA Bioenergy Task 38 - Case Study, Forest Ecosystem Research Group. Department of Environmental Resource Management, University College, Dublin.

Mathur, S.P. and Voisin, B., 1996. The use of compost as greenhouse growth media. Final Report of a Study Conducted for Waste Reduction Branch, Ontario Ministry of Environment and Energy at the Composting Council of Canada.

Marmo, L. 2008. EU strategies and policies on soil and waste management to offset greenhouse gas emissions. Waste Manag., 28: 685-689. 
Moller, J., 2007. Greenhouse gas balance of different waste management strategy. Proceedings Sardinia 2007, Eleventh International Waste Management and Landfill Symposium. S. Margherita di Pula, Cagliari, Italy; 1 - 5 October 2007.

Prasad, M. and Maher, M.J., 2006. Evaluation of composted botanic material as components of a reduced-peat growing media for nursery stock. In: Proceedings of the International Conference ORBIT 2006: Biological Waste Management. From Local to Global. Weimar, 13-15 September. Verlag ORBIT e.V , Weimar, Germany.

Reijnders, L. and Huijbregts, M.A.J., 2003. Choices in calculating life cycle emissions of carbon containing gases associated with forest derived biofuels. J. Clean. Prod. 11: 527-532.

Smith, A.; Brown, K.; Ogilvie, S.; Rushton, K. and Bates, J., 2001. Waste Management Options and Climate Change. Final report to the European Commission, DG Environment. AEA Technology. Office for Official Publications of the European Communities, Luxembourg.

Statistics Denmark. Accessed March 2009 from: www.statistikbanken.dk.

Stranddorf, H.K.; Hoffmann, L., Schmidt, A., 2005. Impact categories, normalisation and weighting in LCA, Updated on selected EDIP97-data. Environmental News No. 782005. Danish Environmental Protection Agency, Danish Ministry of the Environment, Copenhagen, Denmark.

Wenzel, H.; Hauschild, M. and Alting, L., 1997. Environmental Assessment of Products, Vol. 1: Methodology, Tools and Case Studies in Product Development. Kluwer Academic Publishers, Hingham, MA, USA, 1997. 